\title{
Sistem Pakar Mendiagnosa Penyakit Itp (Idiopathic Thormbocytopenict Purpura) Mengunakan Metode Variable Centered Intelligent Rule System (VCIRS)
}

\author{
Mhd. Iskandar Romadon Hasibuan \\ Program Studi Teknik Informatika, STMIK Budi Darma, Medan, Indonesia \\ Email: iskandarramadhan2@gmail.com
}

\begin{abstract}
Abstrak-Pada saat ini penggunaan teknologi perangkat komputer telah berkembang pesat dan memasyarakat. Sebagian besar masyarakat menggunakannya tidak hanya untuk kepentingan secara komersial saja, tetapi juga untuk mendapatkan informasi pendeteksian penyakit secara cepat dan efesien dengan aplikasi berbasis komputer yang dapat membantu masyarakat umum untuk mengetahui penyebab dan gejala dari penyakiit tersebut. Untuk itu, diperlukan suatu sistem yang dirancang untuk dapat menirukan keahlian seorang pakar dalam menjawab pertanyaan dan memecahkan suatu masalah sesuai dengan pengetahuan seorang pakar yang dimasukan kedalam suatu sistem komputer. Perkembangan teknologi Kecerdasan Buatan yang terjadi telah memungkinkan Sistem Pakar untuk diaplikasikan penggunaannya dalam mendeteksi penyakit dengan menggunakan bahasa pemrograman. Salah satunya dalam pemberian informasi mengenai berbagai masalah, terutama penyakit ITP (Idiopathic Thrombocytopenic Purpura). Metode sistem pakar yang digunakan adalah Varibel Centered Intelligent Rule System (VCIRS) digunakan untuk menangani dalam mendiagnosa penyakit ITP. Dengan fasilitas yang diberikan untuk user dan administrator, memungkinkan baik user maupun admnistrator untuk menggunakan sistem ini sesuai kebutuhan masing-masing. User diberi kemudahan dalam mengetahui informasi penyakit ITP, penyebab dan pencegahannya. Sistem Pakar ini dibuat dengan menggunakan Bahasa Pemrograman Microsoft Visual Basic 2008.
\end{abstract}

Kata Kunci: Sistem Pakar, Variabel Centered Intelegent Rule System (VCIRS), ITP

Abstract-At this time the use of computer peripheral technology has grown rapidly and is popular in the community. Most people use it not only for commercial purposes, but also to obtain information on the detection of disease quickly and efficiently with computer-based applications that can help the general public to find out the causes and symptoms of these diseases. For this reason, we need a system designed to be able to mimic the expertise of an expert in answering questions and solving a problem in accordance with the knowledge of an expert entered into a computer system. The development of Artificial Intelligence technology that has occurred has enabled the Expert System to be applied in detecting diseases using the programming language. One of them is in providing information about various problems, especially ITP (Idiopathic Thrombocytopenic Purpura) disease. The expert system method used is the Variable Centered Intelligent Rule System (VCIRS) used to deal with diagnosing ITP disease. With the facilities provided for users and administrators, it allows both users and administrators to use this system according to their individual needs. Users are given the ease of knowing information about ITP disease, its causes and prevention. This Expert System was created using the Microsoft Visual Basic 2008 Programming Language.

Keywords: Expert System, Variable Centered Intelligence Rule System (VCIRS), ITP

\section{PENDAHULUAN}

Idiopathic Thrombocytopenic Purpura (ITP) adalah penyakit kelainan autoimun yang berdampak kepada trombosit atau platelet. Kondisi ini bisa menyebabkan seseorang mudah mengalami memar atau berdarah, dan terjadi secara berlebihan. Pendarahan yang terjadi disebabkan oleh tingkat trombosit yang rendah. ITP ini bisa terjadi kepada orang dewasa dan anak-anak. ITP pada anak-anak biasanya terjadi pasca infeksi virus dan bisa pulih sepenuhnya tanpa melalui pengobatan atau penanganan khusus. Sedangkan pada orang dewasa, ITP biasanya merupakan kelainan yang bersifat kronis atau jangka panjang.

Diagnosis penyakit ITP dilakukan dengan cara memastikan gejala pendarahan maupun jumlah trombosit rendah bukan disebabkan karena penyakit lain. Jika tidak didapati adanya penyebab tertentu, maka bisa disimpulkan pasien mengalami ITP. Prosedur yang bisa dilakukan untuk mendiagnosis ITP adalah: tes darah, tes fisik riwayat kesehatan lengkap, pemeriksaan sum-sum tulang.

Pengobatan ITP tergantung pada tingkat keparahan penyakit itu sendiri. Biasanya anak-anak tidak memerlukan pengobatan. Pada orang dewasa, obat yang umum digunakan adalah steroid. Jika steroid kurang efektif, obat lain seperti immunoglobulin dapat diberikan melalui injeksi ke dalam pembuluh darah. Jika langkahlangkah ini dirasa tidak efektif, kemungkinan limpa perlu diangkat [1].

Sistem pakar adalah sistem yang berusaha mengadopsi pengetahuan manusia ke komputer, agar komputer dapat menyelesaikan masalah seperti yang bisa dilakukan oleh para ahli. Adanya sistem pakar ini, orang awam pun dapat menyelesaikan masalah yang cukup rumit yang sebenarnya.

Variabel centered intelegent rule system (VCIRS) merupakan perkawinan dari SBA dan RDR. Arsitektur sistem diadaptasi dari SBA dan ia mengambil keuntungan-keuntungan yang ada dari RDR. Sistem ini mengorganisasi RB dalam struktur spesial sehingga pembangunan pengetahuan, inferensia pengetahuan yang berdayaguna dan peningkatan evolusional dari kinerja sistem dapat didapatkan pada waktu yang sama. Metode ini merupakan salah satu metode sistem pakar yang mempunyai keunggulan dalam sistem perbaikan data. Jika 
terdapat kesalahan atau pengembangan data dapat dilakukan pembaruan data tanpa harus membuat sistem dari awal [2].

\section{METODE PENELITIAN}

\subsection{Sistem Pakar}

Sistem pakar (expert system) adalah aplikasi berbasis komputer yang digunakan sebagai sarana untuk menyimpan pengetahuan para pakar. Dengan demikian, komputer akan memiliki keahlian untuk menyelesaiakan permasalahan dengan meniru keahlian yang dimiliki oleh pakar. Berbagai aplikasi sistem pakar telah banyak dikembangkan baik dibidang kedokteran, psikologi maupun di bidang yang lain, seperti pengembangan sistem pakar MYCIN untuk diagnosis penyakit [3].

\subsection{Variable Centered Intelligent Rule System (VCIRS)}

Variable-Centered Intelligent Rule System (VCIRS) merupakan perkawinan dari SBA dan RDR. Arsitektur sistem diadaptasi dari SBA dan ia mengambil keuntungan-keuntungan Variable-Centered Intelligent Rule System yang ada dari RDR. Sistem ini mengorganisasi RB dalam struktur spesial sehingga pembangunan pengetahuan, inferensia pengetahuan yang berdayaguna dan peningkatan evolusional dari kinerja sistem dapat didapatkan pada waktu yang sama. Istilah "Intelligent" dalam VCIRS menekankan pada keadaan sistem ini yang dapat "belajar" untuk meningkatkan kinerja sistem dari pengguna sistem selama pembangunan pengetahuan (melalui analisis nilai) dan penghalusan pengetahuan (dengan pembangkitan rule) [6].

VCIRS adalah sistem yang melakukan modifikasi terhadap sistem yang sudah ada (yakni SBA dan RDR) sebagai berikut:

1. SBA

Pembangunan pengetahuan (mudah)

2. RDR

Inferensia (kemampuan inferensia ala SBA)

3. Kinerja sistem

Cakupan pengetahuan (ditingkatkan oleh pembangkitan rule)

Persamaan (1) menghitung VUR untuk variabel ke-i, (2) menghasilkan NUR untuk node ke-j, sedangkan (3) mendefinisikan RUR untuk rule ke- $k$.

$\mathrm{VUR}_{\mathrm{i}}=$ Credit $\times$ Weight $_{i}$

$\mathrm{NUR}_{\mathrm{j}}=\frac{\sum_{1}^{N} V U R_{i j}}{N} \quad \mathrm{VUR}_{\mathrm{ij}}$ untuk variabel ke- $i$ dalam node $j$

$\mathrm{RUR}_{\mathrm{k}}=\frac{\sum_{1}^{N} N U R_{j k}}{N} \quad \mathrm{NUR}_{\mathrm{jk}}$ untuk variabel ke-j dalam rule $k$

Dimana:

a. Credit $_{\mathrm{i}}=$ kejadian dari variable i dalam Node Structure

Credit didapatkan dari node structure. Nilainya akan meningkat saat pengguna membuat node yang menyetujui nilai dari case lama.

b. Weight $_{\mathrm{i}}=\mathrm{NS}_{\mathrm{i}} \times \mathrm{CD}_{\mathrm{i}}$

Weight menghitung bobot (weight) dari variabel ke node yang memilikinya. Ada 2 faktor yang berkonstribusi kebobot dari sebuah variabel. Pertama adalah jumlah node yang berbagi (sharing) sebuah variabel dan kedua adalah CD (Closeness Degree), yaitu derajat kedekatan sebuah variabel pada sebuah node.

$\mathrm{NS}_{\mathrm{i}}=$ jumlah node yang berbagi (sharing) varabel $i$

$\mathrm{CD}_{\mathrm{i}}=\frac{V O_{i}}{T V}$

CD adalah singkatan dari Closeness Degree, yaitu derajat kedekatan sebuah variabel pada sebuah node. $\mathrm{CD}_{\mathrm{i}}$ dalam node $j$, menghitung derajat kedekatan dari variable i dalam node $\mathrm{j}$. Makin dekat sebuah variable pada konklusi yang dipunya suatu node (catatan: node adalah rangkaian dari variable-variable). CD dihitung dengan urutan variabel VO, dibagi dengan total variabel TV, yang dimiliki oleh sebuah node.

$\mathrm{VO}_{\mathrm{i}}=$ urutan dari variabel $i$ dalam suatu node

$\mathrm{TV}=$ total variabel yang dimiliki oleh suatu node

\subsection{Certainly Factor (CF)}

Metode certainty factor digunakan ketika menghadapi suatu masalah yang jawabannya tidak pasti. Ketidakpastian ini bisa merupakan probabilitas. Metode ini diperkenalkan oleh Shortlife Buchanan pada tahun 1970-an. Beliau menggunakan metode ini saat melakukan diagnosis dan terapi terhadap penyakit meningitis dan infeksi darah [7]. Tim pengembang dari metode ini mencatat bahwa, dokter sering kali menganalisa informasi yang ada dengan ungkapan seperti "mungkin", "hampir pasti". Metode ini mirip dengan fuzzy logic, karena ketidakpastian direpresentasikan dengan derajat kepercayaan sedangkan perbedaannya adalah pada fuzzy logic saat perhitungan untuk rule yang premisnya lebih dari satu, fuzzy logic tidak memiliki nilai keyakinan untuk rule tersebut sehingga 
perhitungannya hanya melihat nilai terkecil untuk operator AND atau nilai terbesar untuk operator OR dari setiap premis yang pada rule tersebut berbeda dengan certainty factor yaitu setiap rule memiiki nilai keyakinannya sendiri tidak hanya premis-premisnya saja yang memiliki nilai keyakinan. Certainty factor menunjukkan ukuran kepastian terhadap suatu fakta atau aturan [7].

$\mathrm{CF}[\mathrm{h}, \mathrm{e}]=\mathrm{MB}[\mathrm{h}, \mathrm{e}]-\mathrm{MD}[\mathrm{h}, \mathrm{e}]$

Keterangan :

$\mathrm{CF}[\mathrm{h}, \mathrm{e}]=$ faktor kepastian

$\mathrm{MB}[\mathrm{h}, \mathrm{e}]=$ measure of belief, ukuran kepercayaan atau tingkat keyakinan terhadap hipotesis (h), jika diberikan evidence (e) antara 0 dan 1.

$\mathrm{MD}[\mathrm{h}, \mathrm{e}]=$ measure of disbelief, ukuran ketidakpercayaan atau tingkat keyakinan terhadap hipotesis (h), jika diberikan evidence (e) antara 0 dan 1 . Adapun beberapa kombinasi certainty factor terhadap premis tertentu:

1. Certainty factor dengan satu premis.

$\mathrm{CF}[\mathrm{h}, \mathrm{e}]=\mathrm{CF}[\mathrm{e}] * \mathrm{CF}[$ rule $]=\mathrm{CF}$ [user] $* \mathrm{CF}$ [pakar]

1. Certainty factor dengan lebih dari satu premis.

$\mathrm{CF}[\mathrm{A} \wedge \mathrm{B}]=\operatorname{Min}(\mathrm{CF}[\mathrm{a}], \mathrm{CF}[\mathrm{b}]) * \mathrm{CF} \quad$ [rule]

$\mathrm{CF}[\mathrm{A} \vee \mathrm{B}]=\mathrm{Max}(\mathrm{CF}[\mathrm{a}], \mathrm{CF}[\mathrm{b}]) * \mathrm{CF}$ [rule]

2. Certainty factor dengan kesimpulan yang serupa.

$\mathrm{CF}$ gabungan $[\mathrm{CF} 1, \mathrm{CF} 2]=\mathrm{CF} 1+\mathrm{CF} 2 *(1-\mathrm{CF} 1)$

\subsection{Idiophatic Thrombocytopenic Purpura (ITP)}

Idiophatic thrombocytopenic purpura (ITP) adalah kelainan autoimun yang ditandai dengan trombo-sitopeni yang menetap (di darah tepi angka trombosit < 150 x 109/1) disebabkan karena ikatan antara antibodi dengan antigen trombosit yang akan menyebabkan destruksi yang prematur oleh sistem retikuloendo-thelial, khususnya limpa. Defisiensi trombosit akan mengakibatkan timbulnya ptekie, purpura, dan per-darahan mukokutan maupun perdarahan lain. Dikatakan juga bahwa ITP adalah keadaan trombositopenia (jumlah trombosit yang rendah dengan hasil pemeriksaan darah lengkap lain serta apusan darah tepi normal) pada pasien tanpa ada gejala klinis yang dihubungkan dengan kondisi atau faktor yang menye-babkan trombositopenia (seperti infeksi human immunodeficiency virus (HIV), systemic lupus erythe-matosus, lymphoproliferative disorders, myelodys-plasia, agammaglobulinemia, terapi dengan obat tertentu, alloimmune thrombocytopenia, dan trombo-sitopenia kongenital atau heriditer) [6].

\section{HASIL DAN PEMBAHASAN}

Sebelum adanya sistem komputerisasi pasien harus bertemu lansung untuk berkonsultasi kepada dokter, tentang gejala penyakit yang dideritanya. Setelah dokter sudah mengetahui penyakit yang diderita oleh pasien maka dokter dapat mendiagnosa penyakit yang diderita pasien. Lalu dokter akan memberikan hasil diagnosa kepada pasien. Setelah perkembangan sistem komputer yang semakin maju maka dokter dapat memberikan pengetuannya kedalam sebuah sistem komputer yang dinamakan basis pengetahuan yang dapat disebut sistem pakar. Kemudian basis pengetahuan tersebut dapat menampilkan hasil diagnosa penyakit yang telah ditentukan perhitungan sesuai dengan sistem pakar. Untuk memenuhi syarat-syarat tersebut maka dibuat suatu struktur If-Then yaang dibaca dari database. Program ini diusahakan sesederhana mungkin agar lebih mudah dimengerti pengguna.

Pembuatan program ini berguna sebagai alat bantu user untuk lebih mudah dalam mendiagnosa penyakit pada pasien. Sistem ini akan menyimpan data-data pasien kedalam database program. Selanjutnya sistem berlanjut kesistem selanjutnya untuk mengetahui gejala dan hasil diagnosa penyakit dari pasien. Sistem yang telah dimasukkan formula dengan metode Variable Centered Intelligent Rule System (VCIRS) akan mengolah data gejala penyakit dan akan menampilkan hasil diagnosa penyakit berupa angka persentase hasil diagnosa yang kemudian akan menampilkan keterangan tentang diagnosa penyakit dan bagaimana solusi yang harus dilakukan oleh pasien.

Hasil diagnosa penyakit akan tersimpan kedalam database sistem yang telah dibuat. Sistem ini berguna apabila sewaktu-waktu user ingin melihat kembali data-data dari gejala dan diagnosa penyakit pasien. Dengan sistem ini maka penyimpanan data-data gejala dan diagnosa penyakit akan lebih aman tersimpan didalam sebuah sistem tanpa harus takut kehilangan data-data sebelumnya.

\subsection{Penerapan Metode VCIRS (Variabel Centered Rule System)}

Logika pada metode VCIRS (Variabel centered intellegent rule system) pada tahap pertanyaan atau tahap sesi konsultasi maka akan didapatkan beberapa jumlah variabel yang sesuai dengan nilai Vcirs dari gejala-gejala tersebut. Jika vcirsnya nilai 0 maka akan menujukan bahwa pasien tidak mengalami gejala seperti yang dinyatakan sistem. Apabila user yakin bahwa gejala seperti yang terapat pada sistem, maka user semakin yakin bahwa gejala yang tersebut memang benar dialami manusia, dan semakin tinggi pula hasil perentase keyakinan yang diproleh.

Proses perhitungan presentase keyakinan diawali dengan pemecahan sebuah rule yang dimiliki premis majemuk, menjadi rule yang memiliki premis tunggal. Kemudian masing-masing aturan baru dihitung Vcirs nya, 
sehingga diproleh nilai Vcirs nya untuk masing-masing aturan, kemudian nilai Vcirs tersebut dikombinasikan. Sebagai contoh, proses pemberian bobot pada setiap premis (gejala) sehingga memperoleh presentase keyakinan untuk penyakit ITP.

Sesuai dengan termonologi kepastian Vcirs (Variabel Centered Intellegent Rule System) pengguna konsultasi diberi jabawan dengan masing-masing bobot sesbagai berikut:

Tabel 1. Tabel Nilai User

\begin{tabular}{ccc}
\hline No & User & Nilai user \\
\hline 1. & Tidak & 0.1 \\
2. & Tidak tahu & 0.2 \\
3. & Kurang yakin & 0.4 \\
4. & Cukup yakin & 0.6 \\
5 & Yakin & 0.8 \\
6. & Sangat yakin & 1.0 \\
\hline
\end{tabular}

Berikut adalah tabel gejala-gejala penyakit ITP, secara keseluruhan data dari rule penyakit ITP dalam bentuk tabel dapat dilihat pada tabel dibawah ini:

Tabel 2. Gejala ITP dan Nilai Pakar

\begin{tabular}{cccc}
\hline No & Kode & Gejala Penyakit & Nilai Pakar \\
\hline 1 & IP01 & Memar & 0.8 \\
2 & IP02 & Perdarahan akibat luka yang berlangsung lama & 0.4 \\
3 & IP03 & Perdarahan yang terjadi pada kulit & 0.8 \\
4 & IP04 & Mimisan & 0.2 \\
5 & IP05 & Darah pada urine & 0.4 \\
6 & IP06 & Perdarahan pada gusi & 0.6 \\
7 & IP07 & Perdarahan berlebihan saat menstruasi & 0.6 \\
8 & IP08 & Sangat kelelahan & 0.5 \\
\hline
\end{tabular}

Tabel 3. Tingkat Presentasi

\begin{tabular}{ccc}
\hline No & Tingkat Presentasi & Nilai Kemungkinan \\
\hline 1 & $0-50 \%$ & Sedikit kemungkinan atau kemingkinan kecil \\
2 & $51-79 \%$ & Kemungkinan \\
3 & $80-99 \%$ & Kemungkinan besar \\
4 & $100 \%$ & Sangat yakin \\
\hline
\end{tabular}

Tabel 4. Basis Pengetahuan Solusi

\begin{tabular}{ccl}
\hline No & $\begin{array}{c}\text { Tingkat } \\
\text { Presentasi }\end{array}$ & \\
\hline 1 & $0-50 \%$ & Solusi \\
2 & $51-79 \%$ & $\begin{array}{l}\text { Harus memasukan trombosit yang cukup pada tubuh manusia } \\
\text { Jadwal seperti untuk flu dan pneumia, dapat membantu mencegah masalah akibat } \\
\text { pengobatan, seperti infeksi. Vaksinasi rutin: melakukan vaksinasi sesuai. } \\
\text { Olahraga rutin, seperti berjalan dapat mencegah pengeprosan tulang, tekanan darah tinggi } \\
\text { dan diabetes yang terkait dengan Idiopathic Thrombocytopenic Purpura (ITP) } \\
\text { Memiliki dukungan mental yang kuat, jika anda merasa perlu untuk berbicara dengan } \\
\text { orang lain masalah Idiopathic Thrombocytopenic Purpura (ITP) }\end{array}$ \\
\hline
\end{tabular}

Tampilan Hasil diagnosis beserta nilai analisis VUR, RUR, dan NUR jika kita rancang rule untuk sistem ini maka akan dinyatakan dalam bentuk if-then sesperti dibawah ini:

If Memar Ya

If Perdarahan akibat luka yang berlangsung lebih lama Ya

If Perdarahan yang terjadi di bawah kulit Ya

If Perdarahan dari hidung atau mimisan Ya

If Darah pada urine atau tinja Ya

If Perdarahan pada gusi, terutama setelah perawatan gigi Ya

If Perdarahan berlebihan saat menstruasi Ya

If Sangat kelelahan Ya

Then Idiopathic Thrombocytopenic Purpura (ITP) Ya

Maka dengan demikian dapat disimpulkkan bahwa diagnosis yang dilakukan sistem terhadap pengguna telah sesuai dengan rancangan rule secara manual. Berasarkan pernyataan tersebut maka didapatkan data berupa jumlah variabel dari rule ITP adalah 8 . Secara keseluruhan data dari rule penyakit Idiopathic Thrombocytopenic Purpura (ITP) dalam bentuk tabel dapat dilihat dibawah ini: 
Tabel 5. Tabel Data dari Rule Idiopathic Thrombocytopenic Purpura (ITP)

\begin{tabular}{|c|c|c|c|c|c|}
\hline $\begin{array}{c}\text { Varibel } \\
\text { ID }\end{array}$ & Varibel & $\begin{array}{c}\text { Vaaribel } \\
\text { order }\end{array}$ & Credit & $\begin{array}{c}\text { Numofnode } \\
\text { Id }\end{array}$ & $\begin{array}{c}\text { Total } \\
\text { Variabel }\end{array}$ \\
\hline 1 & Memar & 1 & 1 & 1 & 8 \\
\hline 2 & $\begin{array}{l}\text { Perdarahan akibat luka yang berlangsung lebih } \\
\text { lama }\end{array}$ & 2 & 1 & 1 & 8 \\
\hline 3 & Perdarahan yang terjadi di bawah kulit & 3 & 1 & 1 & 8 \\
\hline 4 & Perdarahan dari hidung atau mimisan & 4 & & 1 & 8 \\
\hline 5 & Darah pada urine atau tinja & 5 & 1 & 1 & 8 \\
\hline 6 & $\begin{array}{l}\text { Perdarahan pada gusi, terutama setelah } \\
\text { perawatan gigi }\end{array}$ & 6 & 1 & 1 & 8 \\
\hline 7 & Perdarahan berlebihan saat menstruasi & 7 & 1 & & 8 \\
\hline 8 & Sangat kelelahan & 8 & 1 & 1 & 8 \\
\hline
\end{tabular}

Berikut ini nilai VUR (varibel usege rate dari 8 gejala Idiopathic Thrombocytopenic Purpura (ITP)).

VUR $=$ Credit $_{x}$ weight $t_{i}$

VUR $=$ Credit $_{x}\left(\right.$ NumOf Nuddeld $\left.\times \frac{\text { Variabel } \text { order }}{\text { Total Variabel }}\right)$

Pada saat pertama kali penggunaan:

\section{VUR dari variabel Memar}

VUR $=$ Credit $_{x}\left(\right.$ NumOf Nuddeld $\left.\times \frac{\text { Variabel } \text { order }}{\text { Total Variabel }}\right)$

VUR $=1_{x}\left(1_{x} \frac{1}{8}\right)$

$$
=0.125
$$

VUR dari variabel Perdarahan akibat luka yang berlangsung lebih lama

VUR $=$ Credit $_{x}\left(\right.$ NumOf Nuddeld $\left.\times \frac{\text { Variabel } \text { Order }}{\text { Total Variabel }}\right)$

VUR $=1_{\mathrm{x}}\left(1_{\mathrm{x}} \frac{2}{8}\right)$

$=0.25$ dan seterusnya

NUR (Node Usege Raten) dari penyakit Idiopathic Thrombocytopenic Purpura (ITP)

NUR $=\frac{\sum V U R}{N j}=0.12+0.25+0.375+0.5+0625+0.75+0.875+1=\frac{4.5}{8}=0.5625$

RUR (Rule Usege Rate) dari penyakit Idiopathic Thrombocytopenic Purpura (ITP)

$$
\begin{aligned}
\text { RUR }_{\mathrm{k}} & =\frac{\sum_{1}^{N} N U R_{j k}}{N} \\
\text { RUR }_{\mathrm{k}} & =\frac{\sum 0.5625}{8} \\
& =0.0703125
\end{aligned}
$$

\begin{tabular}{|c|c|c|}
\hline No & Pertanyaan & Jawaban \\
\hline 1 & $\mathrm{E}_{1}=$ Apakah Badan Selalu Memar ? & Cukup yakin $=0.6$ \\
\hline 2 & $\mathrm{E}_{2}=$ Apakah luka yang lama Selalu Perdarahan ? & Kurang yakin $=0.4$ \\
\hline 3 & $\mathrm{E}_{3}=$ Apakah perdarahan di bawah kaki selalu berbintik merah & Tidak tahu \\
\hline 4 & $\mathrm{E}_{4}=$ Apakah hidung selalu mimisan $?$ & Kurang yakin $=0.4$ \\
\hline 5 & $\mathrm{E}_{5}=$ Apakah Perdarahan pada urine $?$ & Tidak tahu \\
\hline 6 & $\mathrm{E}_{6}=$ Apakah Perdarahan pada gusi $?$ & Yakin \\
\hline 7 & $\mathrm{E}_{7}=$ Apakah Perdarahan berlebihan saat menstruasi ? & Cukup yakin $=0.6$ \\
\hline 8 & $\mathrm{E}_{1}=$ Aapakah selalu sangat kelelahan ? & Kurang yakin $=0.5$ \\
\hline
\end{tabular}

Seorang pasien sedang melakukan diagnosa untuk penyakit Idiopathic Thrombocytopenic Purpura (ITP), pasien tersebut menayakan pertanyaan dengan jawaban berikut:

Tabel 6. Sampel Kasus

Hitung CF $[\mathrm{H}, \mathrm{E}]=\mathrm{CF}[\mathrm{H}] \times \mathrm{CF}[\mathrm{E}]$

$\mathrm{CF}[\mathrm{H}, \mathrm{E}] \times \mathrm{RUR}_{\mathrm{k}}=\mathrm{CFR}$

Dengan :

$\mathrm{CF}[\mathrm{H}]=$ sebagai nilai (pakar)

$\mathrm{CF}[\mathrm{E}]=$ sebagai nilai (jawaban pasien)

$\mathrm{CF}[\mathrm{H}, \mathrm{E}]_{1}$

$\mathrm{CF}[\mathrm{H}, \mathrm{E}]_{1}$

CFR

$$
\begin{aligned}
& =\mathrm{CF}[\mathrm{H}] \times \mathrm{CF}[\mathrm{E}] \\
& =0.8 \times 0.6 \\
& =0.48 \\
& =\mathrm{CF}[\mathrm{H}, \mathrm{E}] \times \mathrm{RUR}_{\mathrm{k}}
\end{aligned}
$$




\begin{tabular}{|c|c|}
\hline & $=0.48 \times 0.0703125$ \\
\hline $\begin{array}{l}\mathrm{CFR}_{1} \\
\text { Sampaai } \mathrm{CFR}_{8}\end{array}$ & $=0.0337$ \\
\hline $\mathrm{CF}[\mathrm{H}, \mathrm{E}]_{8}$ & $=\mathrm{CF}[\mathrm{H}] \times \mathrm{CF}[\mathrm{E}]$ \\
\hline $\mathrm{CF}[\mathrm{H}, \mathrm{E}]_{8}$ & $\begin{array}{l}=0.8 \times 05 \\
=0.16\end{array}$ \\
\hline CFR & $\begin{array}{l}=\mathrm{CF}[\mathrm{H}, \mathrm{E}] \times \mathrm{RUR}_{\mathrm{k}} \\
=0.16 \times 0.0703125\end{array}$ \\
\hline $\mathrm{CFR}_{8}$ & $=0.01125$ \\
\hline
\end{tabular}

Hitung CF kombinasi Idiopathic Thrombocytopenic Purpura (ITP)

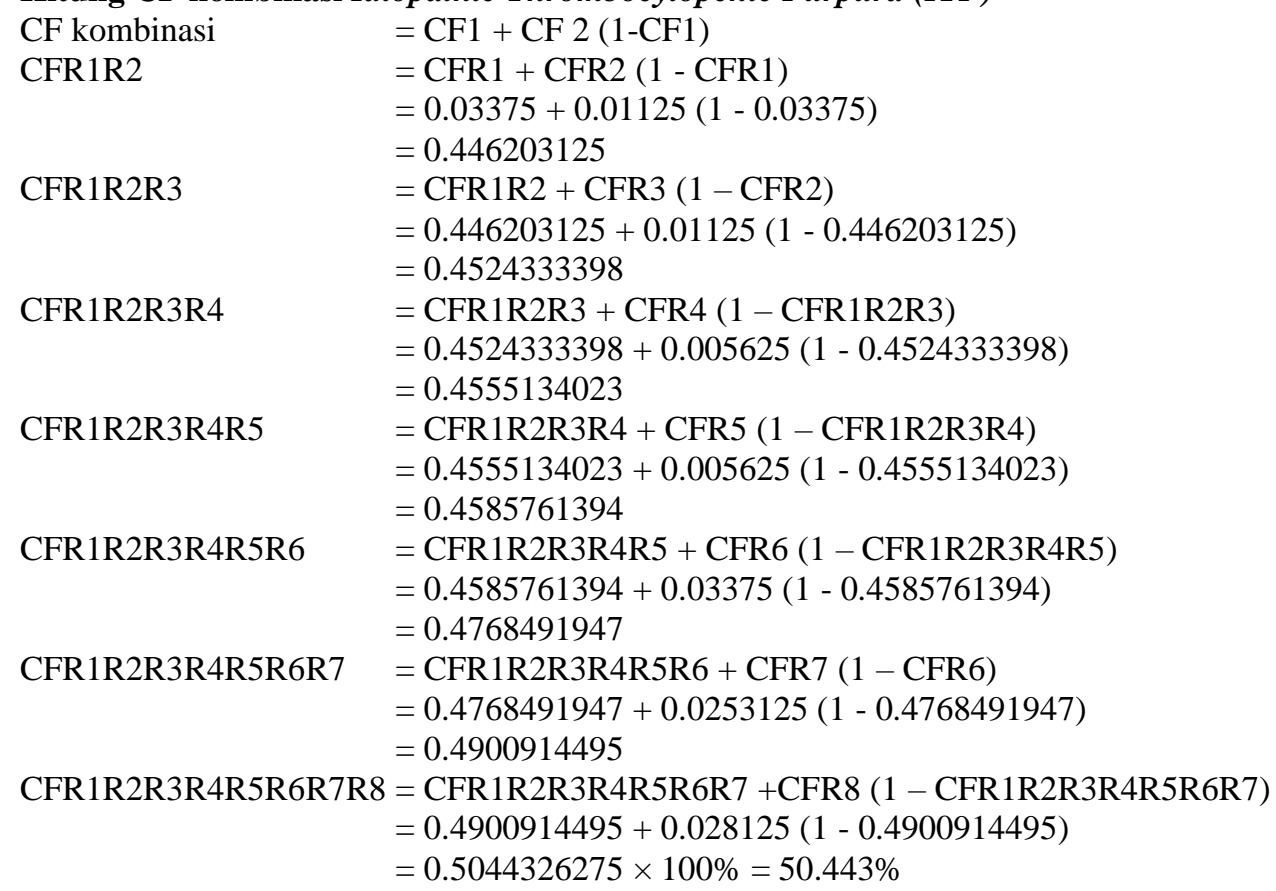

Dari kesimpulan perhitungan diatas maka dapat disimpulkan bahwa pasien mengalami penyakit Idiopathic Thrombocytopenic Purpura (ITP) dengan nilai 50.443\%. Persentase kesimpulan membuktikan bahwa kemungkinan kecil pasien tersebut menderita Idiopathic Thrombocytopenic Purpura (ITP). Maka solusinya adalah dengan mengubah pola hidup menjadi lebih sehat.

\subsection{Implementasi}

Hasil pengujian program menampilkan hasil output dari sebuah input data pada aplikasi yang telah siap. Adapun tampilan hasil pengujian program adalah sebagai berikut:

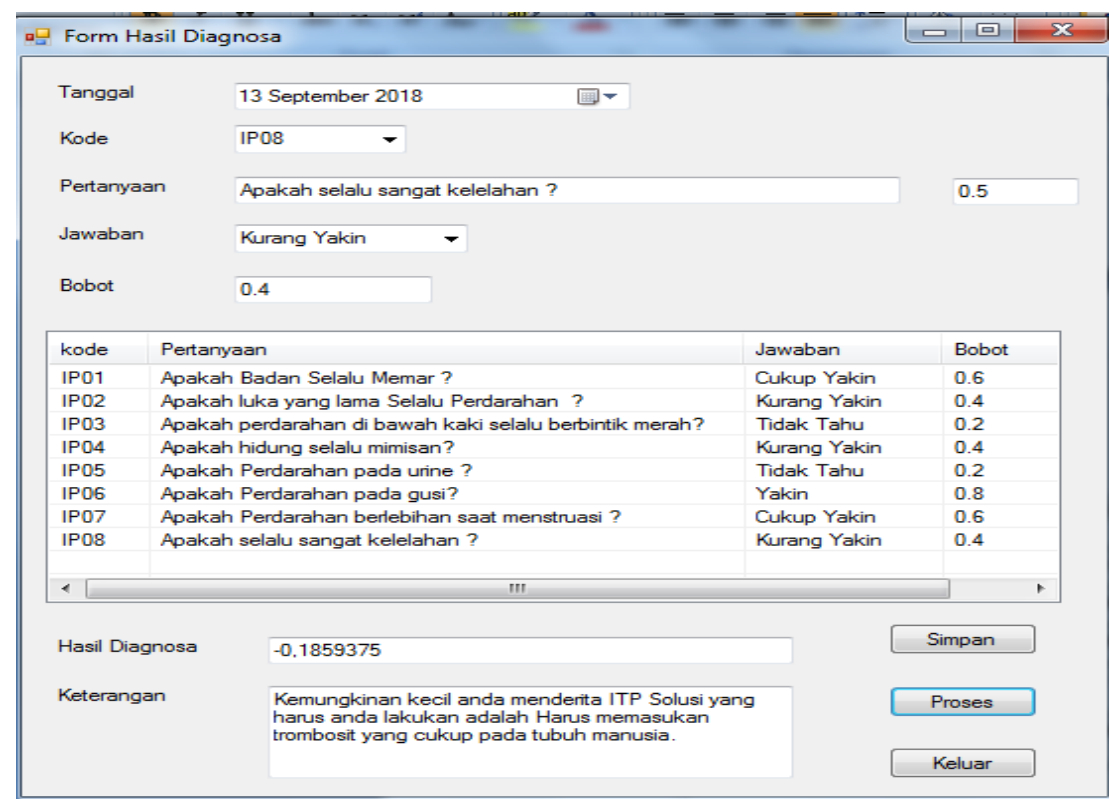

Gambar 1. Tampilan Hasil Diagnosa.

Mhd. Iskandar Romadon Hasibuan, Copyright (C 2020, Jurnal JSON, Page 99 Submitted: 14/01/2020; Accepted: 22/01/2020; Published: 25/01/2020 


\section{KESIMPULAN}

Berdasarkan analisa yang telah dilakukan selama proses perancangan hingga implementasi, maka dapat diambil kesimpulan sebagai berikut:

1. Penyakit Idiopathic Thrombocytopenic Purpura (ITP) dapat didiagnosa dengan menggunakan sistem pakar, untuk membantu masyarakat dalam mengetahui gejala awal dari penyakit Idiopathic Thrombocytopenic Purpura (ITP) yang diderita tanpa harus bertemu dokter, agar tidak tercapai tahap akhir dari penyakit hepatitis yang berujung kematian.

2. Dengan menerapkan metode Variable Centered Intelligent Rule System (VCIRS) dalam mendiagnosa penyakit Idiopathic Thrombocytopenic Purpura (ITP) dapat menghasilkan nilai akurasi, serta memberikan informasi penyakit yang diderita pasien dan bagaimana solusi pencegahannya. Aplikasi sistem pakar mendiagnosa penyakit Idiopathic Thrombocytopenic Purpura (ITP) ini menggunakan bahasa pemrograman Microsoft Visual Basic 2008.

3. Merancang aplikasi sistem pakar mendiagnosa penyakit Idiopathic Thrombocytopenic Purpura (ITP) dapat menampilkan sistem yang dapat membantu masyarakat.

\section{REFERENCES}

[1] Fadilah Zennifa, et al. "Prototipe Alat Deteksi Dini dan mandiri penyakit jantung Menggunakan Sistem Pakar VCIRS, Ardunio dan Handphone Android", Teknik Elektro Universitas Andalas, 2011

[2] Fadilah Zennifa, et al. "Prototipe Alat Deteksi Dini dan mandiri penyakit jantung Menggunakan Sistem Pakar VCIRS, Ardunio dan Handphone Android”, Teknik Elektro Universitas Andalas, 2011.

[3] T. Sutojo, S. Si, M. Kom et al, Kecerdasan Buatan, Yogyakarta, 2011.

[4] Anita Destiani \& Muhammad Arhami, Konsep Kecerdasan Buatan, Yogyakarta, 2006

[5] Muhammad Arhami, Konsep Dasar Sistem Pakar, Yogyakarta, 2005.

[6] Indah Wulansari, Maria Goreti Widiastuti \& Rahardjo, Abses submandibula odontogenik pada penderita idiopatik trombositopeni purpura di RSUP Dr. Sardjito, Yogyakarta, 2016.

[7] Irfan Surbakti, M.Sc.Eng, "Variabel Intelegent Rule System,”, Information and Comunication Technology Seminar, 2006.

[8] Stephanie Halim \& Seng Hansum, Penerapan Metode Certainty Factor dalam Sistem Pakar Pendeteksi Resiko Osteoporosis dan Osteoarthritis, Tangerang, 2015.

[9] Rosa A. S. dan M. Shalahuddin, Rekayasa Perangkat Lunak, Bandung, 2016.

[10] Rahmat Priyanto, Langsung Bisa Visual Basic. NET 2008, Bandung, 2009. 